Article

\title{
Adoption of Systemic and Socio-Technical Perspectives in Waste Management, WEEE and ELV Research
}

\author{
Magnus Andersson, Maria Ljunggren Söderman * ${ }^{\mathbb{D}}$ and Björn A. Sandén \\ Division of Environmental Systems Analysis, Department of Technology Management and Economics, \\ Chalmers University of Technology, SE-41296 Gothenburg, Sweden; andersson.k.magnus@gmail.com (M.A.); \\ bjorn.sanden@chalmers.se (B.A.S.) \\ * Correspondence: maria.ljunggren@chalmers.se; Tel.: +46-31-772-2132
}

Received: 21 January 2019; Accepted: 5 March 2019; Published: 20 March 2019

\begin{abstract}
A greater quantity and variety of materials are being produced worldwide to meet demand for consumer products, buildings and infrastructure. Additionally, highly diffused products such as cars and electronics have become materially complex and depend on numerous scarce metals. Consequently, managing the societal supply of a variety of materials and metals sustainably is becoming increasingly important. This includes the use of efficient and effective waste management. However, the current management of waste in general and of waste consumer products specifically, have been pointed out as requiring significant developments to become more advanced to cope with the increasing material complexity. It has also been pointed out that research taking systems perspectives is crucial to improve waste management. Additionally, researching change processes and the co-evolution of social and technical factors (i.e., socio-technical change), has furthered the understanding of how 'green' industries develop in other empirical fields. Consequently, both systemic and socio-technical perspectives are likely relevant to waste management research. We used the Scopus database to search for 31 research approaches associated with such perspectives in journal articles writing about waste management in general, waste electrical and electronic equipment (WEEE) or end-of-life vehicles (ELVs). We conclude that, although the majority of the examined research does not mention the considered approaches, some environmental system analysis approaches are frequently mentioned and show signs of growth in adoption. In contrast, socio-technical approaches are scarcely mentioned. Consequently, we argue that there are relevant scientific tools yet to be adopted in waste management, WEEE and ELV research.
\end{abstract}

Keywords: waste management; waste electrical and electronic equipment (WEEE); end-of-life vehicle (ELV); environmental system analysis (ESA); socio-technical change; sustainability transition

\section{Introduction}

A greater quantity and variety of materials and metals are being produced worldwide to meet demand for consumer products, buildings and infrastructure [1,2]. The demand for some scarce metals in particular has been associated with concerns over potential metal supply disruptions to some regions (e.g., EU, Japan, U.S.), since the mining of many scarce metals is concentrated to a few countries outside these regions [3,4]. Additionally, global depletion of high grade ore due to intense mining has long been a concern, since mining lower grade ores would require significantly more resources with negative consequences for the environment and welfare overall [5]. The increasingly widespread use of complex materials and scarce elements is saliently exemplified by products such as cars and electronic devices, which depend on multiple steel and aluminium alloys, a variety of plastics, 
and numerous scarce metals [6-10]. Consequently, waste streams are also becoming more complex [11]. Hence, efficient and effective waste management and the recovery of materials and scarce metals have been pointed out as key to achieve resource sustainability and a circular economy [2,3,12-14].

However, global average recycling rates of many scare metals are estimated to be less than $1 \%[13,15]$. In fact, scarce metals are likely to be irreversibly lost in current waste management systems $[6,8,9]$. In particular, the waste management of consumer products has been pointed out as requiring significant development to become more metal and product specific if recycling rates of scarce metals are to be raised $[13,16,17]$. The challenges involved are thus large and remedies would include addressing political, social and technical issues to enable the development of more advanced waste management industries [13,18-20]. Hence, more research is arguably needed to uncover ways for moving towards more sustainable resource management. It has been pointed out that research taking systems perspectives is crucial for underpinning decisions on how to improve waste management (see e.g., Marshall and Farahbakhsh [21], and Seadon [22]). Additionally, in other empirical fields such as renewable energy and electric mobility, researching change processes and the co-evolution of social and technical factors (i.e., socio-technical change), has furthered the understanding of how 'green' industries develop [23,24].

Consequently, systemic and socio-technical perspectives arguably need to be reflected in the research approaches adopted in waste management research in general, and in research associated with complex consumer waste such as waste electrical and electronic equipment (WEEE) and end-of-life vehicles (ELVs). Previous studies have focused on specific waste management fields and reviewed the use of specific systems analysis tools, such as life cycle assessment [25-31], material flow analysis [32], or cost-benefit analysis [33]. Other studies have taken several research approaches into consideration and analysed how these approaches can be used for specific purposes, such as analysing material flows [34,35], or creating decision-support [36]. However, the uptake of systemic and socio-technical perspectives in waste management research in general has not been addressed, or the application of such perspectives in WEEE and ELV research. Hence this study aims at filling this gap and investigates to what extent systemic and socio-technical perspectives are represented in waste management, WEEE, and ELV research. In the narrower fields of WEEE and ELV research, we also briefly explore what other types of research approaches are being used, to underpin a discussion on the focus and balance of current knowledge production. We aim to answer the following research questions:

1. To what extent are environmental systems analysis and socio-technical change approaches adopted in current waste management, WEEE and ELV research?

2. How has the adoption of environmental systems analysis and socio-technical change approaches in waste management, WEEE and ELV research changed over time?

3. If these approaches only make up a small fraction of WEEE and ELV research, what types of other approaches are frequently applied?

\section{Materials and Methods}

We searched for current use, and trends in use, of environmental system analysis (ESA) and socio-technical (ST) change research approaches within three empirical waste management fields: (1) waste management in general (WM), (2) waste electrical and electronic equipment (WEEE), and (3) end-of-life vehicles (ELVs). The two narrower fields, management of WEEE and ELVs, are examples of areas with particularly large waste management challenges regarding the recycling of individual scarce metals. For these, we also examined the use of other research approaches.

The study is based on journal articles available in the Scopus database, one of the most comprehensive databases for peer reviewed literature [37]. All search queries were limited to extracting data from article titles, abstracts and author keywords. The results of the conducted research focus on articles published in the 10-year period 2008-2017, which was chosen to represent current research. Additionally, in order to study trends, articles published in the 30-year period 1988-2017 were considered. Procedurally, we performed the following steps: 
1. Identification of relevant search terms, that can be associated with ESA and ST research approaches and the three empirical fields (i.e., WM, WEEE, ELVs).

2. Quantification of articles that use the identified terms associated with ESA or ST research approaches and empirical fields.

3. Quantification and characterisation of articles in the WEEE and ELV fields that do not use any of the identified terms associated with ESA or ST approaches.

Steps 1-3 are explained in detail in Sections 2.1-2.3. Results from steps 2-3 are reported in Section 3. Subsequently, in Section 4, we discuss the types of approaches used, and the implications for what types of knowledge are created within the examined empirical fields.

\subsection{Identification of Relevant Search Terms}

To identify relevant search terms that can catch articles associated with ESA and ST research approaches, we relied on creating search terms based on the names of commonly used research approaches mentioned in literature. Specifically, for ESA approaches we selected approaches that to some extent take a multidimensional and/or a systems perspective and are mentioned by Allesch and Brunner [38], Finnveden et al. [36], or Zurbrügg et al. [39], as relevant assessment or decision support tools in research related to environmental sustainability of waste management. For ST approaches, we selected approaches mentioned by Markard et al. [23], Sovacool [40], Sovacool and Hess [41], or van den Bergh et al. [24], as commonly used for studying socio-technical change towards sustainability. Although there is cross-fertilization between many approaches within each group (ESA and ST), we divide them into categories to visualize some differences (Table 1). Among ESA approaches, we distinguish five broad categories made up of: (1) methods that focus on an energy dimension (emergy, energy, entropy, exergy analysis); (2) methods aimed at quantifying physical flows of goods, materials or substances (material flow accounting/analysis and substance flow analysis); (3) approaches associated with assessing environmental impacts (ecological footprint, environmental impact assessment, life cycle assessment, life cycle inventory, strategic environmental assessment); (4) approaches emphasizing an economic dimension (cost-benefit analysis; eco-efficiency analysis; input-output analysis; life cycle costing; systems of environmental and economic accounting); and (5) other approaches, including multi criteria decision making (used to rank and prioritize in decision making processes), risk assessment (used to evaluate e.g., implications of hazardous substances) and stakeholder analysis (used to e.g., assess the impact of a decision on different actors). Among ST approaches, we distinguish two categories made up of: (1) approaches with an emphasis on describing, explaining or addressing socio-technical change through system perspectives; and (2) approaches that emphasize actor involvement, social construction and social change in such change processes. The selected approaches were converted to search strings according to Table A1.

To identify search terms relevant to the empirical fields, we first selected a set of initial search terms and used these to execute preliminary search queries. Subsequently, from the yielded results, we selected some keywords (provided by Scopus) as additional terms to represent the empirical fields under study. This was done to avoid limiting results to only terms generated by the authors, and to grow the number of covered relevant articles.

The selection of initial terms and subsequently of keywords were made with the aim of catching as many articles as possible associated broadly with WM, WEEE and ELVs. Consequently, we aimed to avoid selecting terms and keywords that would expand search results beyond these empirical fields and to avoid selecting very specific terms and keywords that would restrict results or yield results skewed towards narrow empirical fields.

The initial search terms were "waste management", "circular economy", "electrical waste", "electronic waste", "end-of-life vehicle" and "end-of-life car". The first two were selected to generate keywords that traditionally and more recently are associated with waste management, and the remaining ones to generate a variety of WEEE and ELV keywords. When forming search queries from these initial terms, we used proximity operators to favour the retrieval of articles where terms 
Table 2. Final set of search terms used to capture the empirical fields under study, i.e., waste management, waste electrical and electronic equipment (WEEE), and end-of-life vehicles (ELVs). As terms were added, the total number of search results grew (columns 3-4). Period 2017 or earlier.

\begin{tabular}{|c|c|c|c|}
\hline Empirical Field & Search Term(s) & $\begin{array}{l}\text { Accumulated No. } \\
\text { of Search Results }\end{array}$ & $\begin{array}{l}\text { No. of Added } \\
\text { Search Results }\end{array}$ \\
\hline \multicolumn{4}{|l|}{ Waste management } \\
\hline & Waste management & 22,131 & - \\
\hline & Waste disposal & 39,782 & 17,651 \\
\hline & Recycling & 53,092 & 13,310 \\
\hline & Municipal solid waste & 61,009 & 7917 \\
\hline & Solid waste management & 61,016 & 7 \\
\hline & Solid waste(s) & 71,870 & 10,854 \\
\hline & Landfill, or Land fill & 84,420 & 12,550 \\
\hline & Refuse disposal & 84,998 & 578 \\
\hline & Waste treatment & 101,467 & 16,469 \\
\hline & Waste incineration & 103,222 & 1755 \\
\hline & Composting & 109,344 & 6122 \\
\hline & Hazardous waste & 113,264 & 3920 \\
\hline & Industrial waste & 123,837 & 10,573 \\
\hline & Circular economy & 124,583 & 746 \\
\hline & Industrial ecology & 126,055 & 1472 \\
\hline & Industrial symbiosis & 126,255 & 200 \\
\hline \multicolumn{4}{|l|}{ WEEE } \\
\hline & WEEE & 1636 & - \\
\hline & Electronic(s) recycling & 2144 & 508 \\
\hline & Electrical recycling & 2229 & 85 \\
\hline & Printed circuit board(s) recycling & 2341 & 112 \\
\hline & E-waste & 3359 & 1018 \\
\hline & Electronic(s) waste & 4049 & 690 \\
\hline & Electrical waste & 4495 & 446 \\
\hline & Printed circuit board(s) waste & 4808 & 313 \\
\hline & E-scrap & 4824 & 16 \\
\hline & Electronic(s) scrap & 4824 & 0 \\
\hline & Electrical scrap & 4854 & 30 \\
\hline & Printed circuit board(s) scrap & 4875 & 21 \\
\hline \multicolumn{4}{|l|}{ ELVs } \\
\hline & End-of-life automobile(s) & 18 & - \\
\hline & End-of-life automotive(s) & 52 & 34 \\
\hline & End-of-life vehicle(s)/motor vehicle(s) & 454 & 402 \\
\hline & End-of-life car(s) & 465 & 11 \\
\hline & Automobile(s) recycling & 546 & 81 \\
\hline & Automotive(s) recycling & 653 & 107 \\
\hline & Vehicle(s)/Motor vehicle(s) recycling & 735 & 82 \\
\hline & Car(s) recycling & 848 & 113 \\
\hline & Automobile(s) waste & 899 & 51 \\
\hline & Automotive(s) waste & 963 & 64 \\
\hline & Vehicle(s) waste & 997 & 34 \\
\hline & Car(s) waste & 1007 & 10 \\
\hline & Motor vehicle(s) waste & 1007 & 0 \\
\hline & Automobile(s) scrap & 1098 & 91 \\
\hline & Automotive(s) scrap & 1147 & 49 \\
\hline & Vehicle(s)/Motor vehicle(s) scrap & 1181 & 34 \\
\hline & Car(s) scrap & 1237 & 56 \\
\hline
\end{tabular}




\subsection{Quantification of Articles that Use Identified Terms}

For each research approach and empirical field, we executed search queries by combining one unique search string related to an approach (Table A1) with the entire set of search strings for each field (Table A6). Additionally, for each empirical field we checked for articles that use terms related to multiple approaches, which may be the case in review articles, for example. Hence, we yielded results indicating the number of articles in each field that in some way are associated with one approach or several. For each approach, we also checked how many articles are published in total (regardless of empirical field), to indicate how many articles are published within the studied empirical fields and how many relate to other fields. When examining the adoption of research approaches in current research, search results were limited to the 10-year period 2008-2017. When trends in adoption were examined instead, the 30-year period 1988-2017 was considered.

\subsection{Quantification and Characterisation of Articles that do not Use Any Identified Terms Associated with Research Approaches}

To quantify articles in current WEEE and ELV research not using any of the selected research approaches, we executed search queries that included results with search strings from the WEEE and ELV fields (Table A6), and excluded results related to the identified ESA and ST approaches (Table A1). Search results were limited to the 10-year period 2008-2017.

The characterisation was done manually by reading article titles, abstracts and keywords. In some cases, if characterisation could not be made otherwise, the main text of the article was read. Additionally, we only studied the largest groups of articles citing each other. Such articles have been deemed relevant to each other in some way by the authors of the articles. We studied the approaches used in these articles, as a way of indicating important types of approaches utilised in the fields. The grouping was done using VOSviewer [42], which automatizes the process of connecting articles that cite each other. Moreover, if such groups still were too large for manual examination, we only studied the most well-cited articles. The aim of this characterisation procedure was to isolate articles using similar approaches, to facilitate a discussion on what knowledge is created overall in the empirical fields. Thus, note that that this step was not aimed at performing a comprehensive literature review.

\section{Results}

\subsection{Quantification of Articles that Use Identified Terms}

Results from executing search queries using all search strings for each empirical field (Table A6), in combination with strings related to one research approach or combinations of them (Table A1), are displayed for current research (the period 2008-2017) in Tables 3-5.

The salient result is that, in all three empirical fields, articles not mentioning ESA or ST approaches dominate heavily, as shown in Tables 3-5. Furthermore, Table 3 indicates that in the WM field, among the approaches selected for study, by far the most frequently mentioned are of ESA type. Among these, life cycle assessment tops the list at over 1000 articles. In descending order then follows risk assessment, material flow accounting/analysis, multi criteria decision making, environmental impact assessment, substance flow analysis, and cost-benefit analysis at above 100 articles each. Several other approaches are mentioned to a lesser extent. Furthermore, although seemingly only a few WM articles use ESA-related terms, for some ESA approaches WM articles still make up a considerable share of all published articles using the ESA terms (i.e., irrespective of empirical field): substance flow analysis, material flow accounting/analysis, life cycle inventory/assessment, and emergy analysis stand out in this regard (Table 3, column 4). Thus, these approaches can be considered as well-adopted in the WM management field, despite the apparent lack of articles among WM results. Hence, these results to some extent reflect what has been expressed in literature, i.e., that system perspectives are highly relevant to waste management research [21,22]. Particularly, this seems true for life cycle 
assessment and material flow accounting/analysis, which are among the most frequently mentioned of the selected approaches (Table 3, columns 2-3), and also are mentioned significantly by WM type articles (Table 3, column 4). In contrast, few articles mention ST approaches. The ones that do, use ST approaches to for instance: analyse competition, through the multi-level perspective, between different district heating solutions (incl. municipal solid waste incineration) in China [43]; explain developments, through actor-network theory, in Swedish nuclear waste management [44]; explain drivers, through large technical systems, behind historic biogas industry developments in Sweden [45]; explain, through innovation system theory and transition management, the transition of waste management in Manchester (UK) from a landfill model to one using recycling, composting and energy production [46]. Hence, such articles explain aspects of development that studies using ESA approaches could not.

Table 3. Articles mentioning ESA or ST approaches, and remaining articles, in the waste management (WM) field, and in total. Period 2008-2017.

\begin{tabular}{|c|c|c|c|}
\hline Research Approach & $\begin{array}{l}\text { No. of Articles in } \\
\text { the WM Field }\end{array}$ & $\begin{array}{c}\text { Share of WM } \\
\text { Articles }\end{array}$ & $\begin{array}{l}\text { Share of all Articles } \\
\text { Mentioning Approach }\end{array}$ \\
\hline \multicolumn{4}{|l|}{ ESA: } \\
\hline Life cycle assessment & 1371 & $2.2 \%$ & $17.8 \%$ \\
\hline Risk assessment & 640 & $1.0 \%$ & $1.3 \%$ \\
\hline Multiple ESA terms & 310 & $0.5 \%$ & $16.0 \%$ \\
\hline Material flow accounting/analysis & 305 & $0.5 \%$ & $46.5 \%$ \\
\hline Multi criteria decision making & 162 & $0.3 \%$ & $3.5 \%$ \\
\hline Environmental impact assessment & 133 & $0.2 \%$ & $6.3 \%$ \\
\hline Substance flow analysis & 118 & $0.2 \%$ & $53.6 \%$ \\
\hline Cost-benefit analysis & 101 & $0.2 \%$ & $2.1 \%$ \\
\hline Input-output analysis & 72 & $0.1 \%$ & $5.9 \%$ \\
\hline Life cycle inventory & 62 & $0.1 \%$ & $19.0 \%$ \\
\hline Ecological footprint & 54 & $0.1 \%$ & $5.3 \%$ \\
\hline Exergy analysis & 53 & $0.1 \%$ & $2.0 \%$ \\
\hline Emergy analysis & 44 & $0.1 \%$ & $15.1 \%$ \\
\hline Energy analysis & 28 & $0.04 \%$ & $0.8 \%$ \\
\hline Stakeholder analysis & 17 & $0.03 \%$ & $2.3 \%$ \\
\hline Life cycle costing & 11 & $0.02 \%$ & $5.1 \%$ \\
\hline Strategic environmental assessment & 9 & $0.01 \%$ & $2.1 \%$ \\
\hline SUM & 3490 & $5.5 \%$ & $4.2 \%$ \\
\hline \multicolumn{4}{|l|}{ ST: } \\
\hline The multi-level perspective & 7 & $0.01 \%$ & $3.0 \%$ \\
\hline Actor-network theory & 5 & $0.01 \%$ & $0.3 \%$ \\
\hline Strategic niche management & 4 & $0.01 \%$ & $5.9 \%$ \\
\hline Large technical systems & 3 & $0.005 \%$ & $9.7 \%$ \\
\hline Social practice theory & 3 & $0.005 \%$ & $0.4 \%$ \\
\hline Technological innovation systems & 2 & $0.003 \%$ & $1.5 \%$ \\
\hline National innovation systems & 1 & $0.002 \%$ & $0.2 \%$ \\
\hline Transition management & 1 & $0.002 \%$ & $0.4 \%$ \\
\hline SUM & 26 & $0.04 \%$ & $0.8 \%$ \\
\hline Other (remaining WM articles) & 59,590 & $94.4 \%$ & - \\
\hline Total sum & 63,106 & $100.0 \%$ & - \\
\hline
\end{tabular}

In the WEEE and ELV fields, again by far the most frequently mentioned approaches are of ESA type (Tables 4 and 5). Among these, risk assessment tops the list in the WEEE field, followed by life cycle assessment, material flow accounting/analysis and substance flow analysis (Table 4). In the ELV field, life cycle assessment and material flow accounting/analysis stand out somewhat (Table 5). The use of risk assessment in the WEEE field is plausibly connected to the concern over implications 
of hazardous substance in WEEE, exemplified by numerous studies using risk assessment to study hazardous WEEE conditions in China, see e.g., Chan et al. [47], Leung et al. [48], or Li et al. [49]. The use of life cycle assessment, material flow accounting/analysis and substance flow analysis can likely be attributed to these approaches being fundamental to much of the WM field in general (Table 3). Hardly any articles use terms related to ST approaches, indicating a widespread lack of their adoption. The exceptions include e.g., the use of actor-network theory to explore actor perceptions of UK WEEE management [50] and use of the multi-level perspective to explore tensions between electronics production and waste management [51].

Table 4. Articles mentioning ESA or ST approaches, and remaining articles, in the WEEE field, and in total. Period 2008-2017.

\begin{tabular}{cccc}
\hline Research Approach & $\begin{array}{c}\text { No. Of Articles in } \\
\text { the WEEE Field }\end{array}$ & $\begin{array}{c}\text { Share of WEEE } \\
\text { Articles }\end{array}$ & $\begin{array}{c}\text { Share of all Articles } \\
\text { Mentioning Approach }\end{array}$ \\
\hline ESA: & & & \\
\hline Risk assessment & 83 & $2.5 \%$ & $0.2 \%$ \\
Life cycle assessment & 61 & $1.9 \%$ & $0.8 \%$ \\
Material flow accounting/analysis & 27 & $0.8 \%$ & $4.4 \%$ \\
Multiple ESA terms & 16 & $0.5 \%$ & $0.8 \%$ \\
Substance flow analysis & 13 & $0.4 \%$ & $5.9 \%$ \\
Multi criteria decision making & 9 & $0.3 \%$ & $0.2 \%$ \\
Environmental impact assessment & 7 & $0.2 \%$ & $0.3 \%$ \\
Cost-benefit analysis & 4 & $0.1 \%$ & $0.1 \%$ \\
Life cycle inventory & 3 & $0.1 \%$ & $0.9 \%$ \\
Ecological footprint & 2 & $0.1 \%$ & $0.2 \%$ \\
Energy analysis & 2 & $0.1 \%$ & $0.1 \%$ \\
Exergy analysis & 2 & $0.1 \%$ & $0.1 \%$ \\
Input-output analysis & 2 & $0.1 \%$ & $0.2 \%$ \\
Emergy analysis & 1 & $0.03 \%$ & $0.3 \%$ \\
Stakeholder analysis & 1 & $0.03 \%$ & $0.1 \%$ \\
SUM & 233 & $7.1 \%$ & $0.3 \%$ \\
\hline ST: & & & \\
\hline Other (remaining WEEE articles) & 3039 & $0.1 \%$ & - \\
\hline Total sum & 3278 & $0.03 \%$ & $0.3 \%$ \\
Transition management & 1 & $0.03 \%$ & $0.4 \%$ \\
SUM & 1 & $0.2 \%$ & $0.3 \%$ \\
\hline Share of the total number of published articles mentioning the research approach. & \\
\hline The multi-level perspective & 6 & $100.0 \%$ & - \\
\hline
\end{tabular}

Regarding trends, the share of articles mentioning any of the selected approaches is growing moderately for some approaches and in some fields. The share of WM articles using ESA terms has grown from ca $1 \%$ to $6 \%$ (from 20 to 540 articles/year in absolute terms) over the last 30 years (Figure 1). A large part of this increase is due to an increasing use of life cycle assessment/inventory terms. This can potentially be attributed to the high use of life cycle assessment as an environmental assessment tool in general, and that this tool has been used to a significant extent to analyse environmental implications of different waste management solutions [52]. Additionally, there has been an increasing number of WM articles using ST terms in recent years, potentially indicating an adoption trend of ST approaches. However, the low number of articles makes this observation highly uncertain (Figure 2). 
Table 5. Articles mentioning ESA or ST approaches, and remaining articles, in the ELVs field, and in total. Period 2008-2017.

\begin{tabular}{cccc}
\hline Research Approach & $\begin{array}{c}\text { No. of Articles in } \\
\text { the ELV Field }\end{array}$ & $\begin{array}{c}\text { Share of ELV } \\
\text { Articles }\end{array}$ & $\begin{array}{c}\text { Share of all Articles } \\
\text { Mentioning Approach }\end{array}$ \\
\hline ESA: & & & \\
\hline Life cycle assessment & 30 & $4.5 \%$ & $0.4 \%$ \\
Material flow accounting/analysis & 17 & $2.6 \%$ & $2.8 \%$ \\
Cost-benefit analysis & 8 & $1.2 \%$ & $0.2 \%$ \\
Input-output analysis & 5 & $0.8 \%$ & $0.4 \%$ \\
Risk assessment & 5 & $0.8 \%$ & $0.0 \%$ \\
Multiple ESA approaches & 4 & $0.6 \%$ & $0.2 \%$ \\
Substance flow analysis & 4 & $0.6 \%$ & $1.8 \%$ \\
Multi criteria decision making & 3 & $0.5 \%$ & $0.1 \%$ \\
Ecological footprint & 1 & $0.2 \%$ & $0.1 \%$ \\
Emergy analysis & 1 & $0.2 \%$ & $0.3 \%$ \\
Energy analysis & 1 & $0.2 \%$ & $0.0 \%$ \\
Exergy analysis & 1 & $0.2 \%$ & $0.0 \%$ \\
SUM & 80 & $12.1 \%$ & $0.1 \%$ \\
\hline ST: & & & \\
\hline Technological innovation systems & 1 & $0.2 \%$ & $0.7 \%$ \\
SUM & 1 & $0.2 \%$ & $0.7 \%$ \\
\hline Other (remaining ELV articles) & 580 & $87.7 \%$ & - \\
\hline Total sum & 661 & $100.0 \%$ & - \\
\hline
\end{tabular}

${ }^{1}$ Share of the total number of published articles mentioning the research approach.

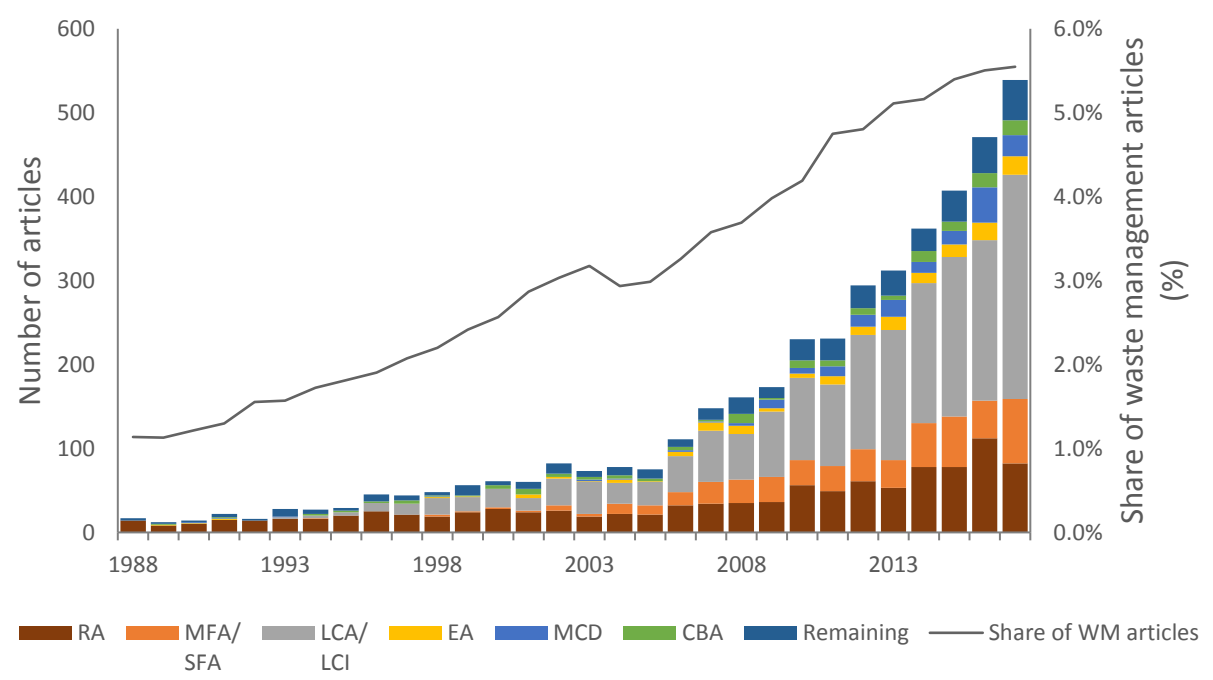

Figure 1. Number of articles per year, and the annual share (displayed as a three-year moving average) of all WM articles, published in 1988-2017 mentioning an ESA approach. Articles mentioning risk assessment are reported as "RA", material flow accounting/analysis or substance flow analysis as "MFA/SFA", life cycle assessment/inventory as "LCA/LCI", energy, entropy, emergy or exergy analysis as "EA", multi criteria decision making as "MCD", cost-benefit analysis as "CBA", other studied approaches as "Remaining". 


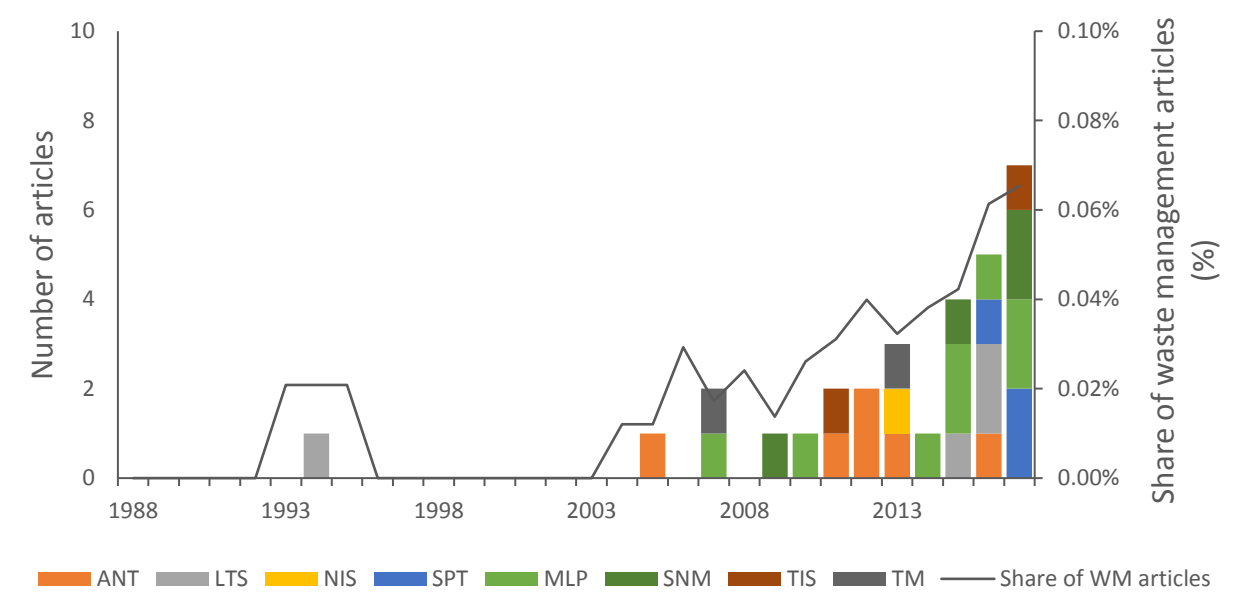

Figure 2. Number of articles per year, and the annual share (displayed as a three-year moving average) of all WM articles, published in 1988-2017 mentioning an ST approach. Articles mentioning actor-network theory are reported as "ANT", large technical systems as "LTS", national innovation systems as "NIS", social practice theory as "SPT", the multi-level perspective on socio-technical transitions as "MLP", strategic niche management as "SNM", technological innovation systems as "TIS" and transition management as "TM".

In the WEEE field, terms associated with life cycle assessment/inventory, risk assessment, material flow accounting/analysis and substance flow analysis are increasingly being used post ca 2007 (Figure 3). It is notable that the jump in the share of WEEE articles using ESA terms occurring in 2000, is related to the low number of WEEE articles being produced at the time (i.e., although search results returned only two articles mentioning ESA terms in 2000, these articles greatly impact on the share displayed in Figure 3). The jump and the increasing number of published articles and use of ESA approaches shortly after, coincide with the introduction of the first EU WEEE directive (Directive 2002/96/EC) and the directive restricting the use of hazardous substances in electrical and electronic equipment (RoHS Directive 2002/95/EC), which came into force in early 2003. No growing trend in the use of ST terms can be identified (Figure 4).

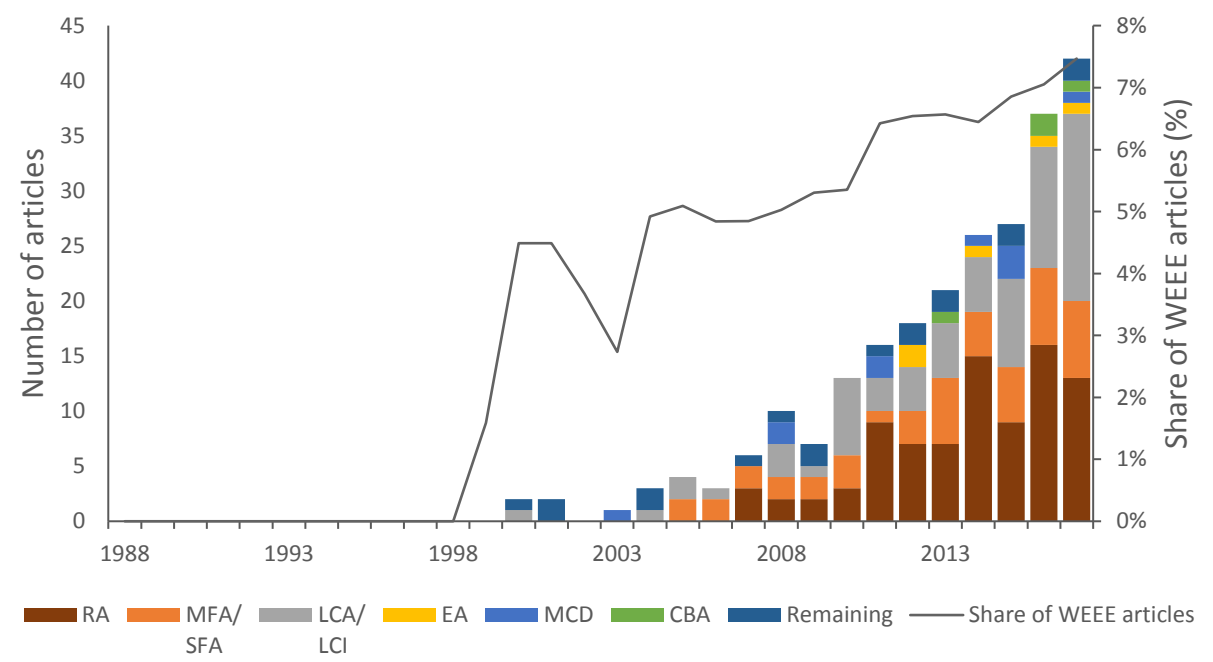

Figure 3. Number of articles per year, and the annual share (displayed as a three-year moving average) of all WEEE articles, published in 1988-2017 mentioning an ESA approach. Articles mentioning risk assessment are reported as "RA", material flow accounting/analysis or substance flow analysis as "MFA/SFA", life cycle assessment/inventory as "LCA/LCI", energy, entropy, emergy or exergy analysis as "EA", multi criteria decision making as "MCD", cost-benefit analysis as "CBA", other studied approaches as "Remaining". 


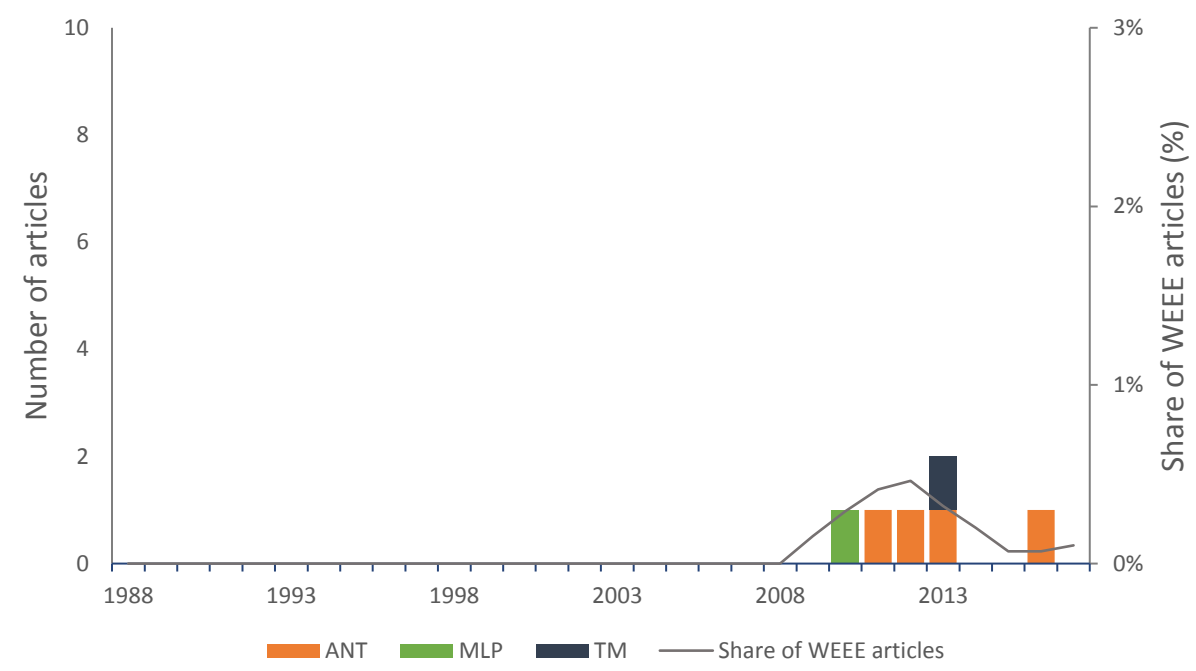

Figure 4. Number of articles per year, and the annual share (displayed as a three-year moving average) of all WEEE articles, published in 1988-2017 mentioning an ST approach. Articles mentioning actor-network theory are reported as "ANT", the multi-level perspective on socio-technical transitions as "MLP" and transition management as "TM".

In the ELV field there is potentially an ongoing adoption trend of life cycle assessment/inventory, material flow accounting/analysis and substance flow analysis approaches, indicated by that articles mentioning these approaches make up most of the observable rise in the share of ELV articles using ESA terms (Figure 5). However, since the number of articles mentioning those same approaches is irregular over time there is not yet strong support for this. The increase in ELV articles and use of ESA tools also coincide with the introduction of EU regulation: the ELV directive (Directive 2000/53/EC), which came into force in 2000. Regarding the use of ST terms, only one ELV related article was identified (thus no figure is provided), i.e., there is no observable adoption trend of ST approaches.

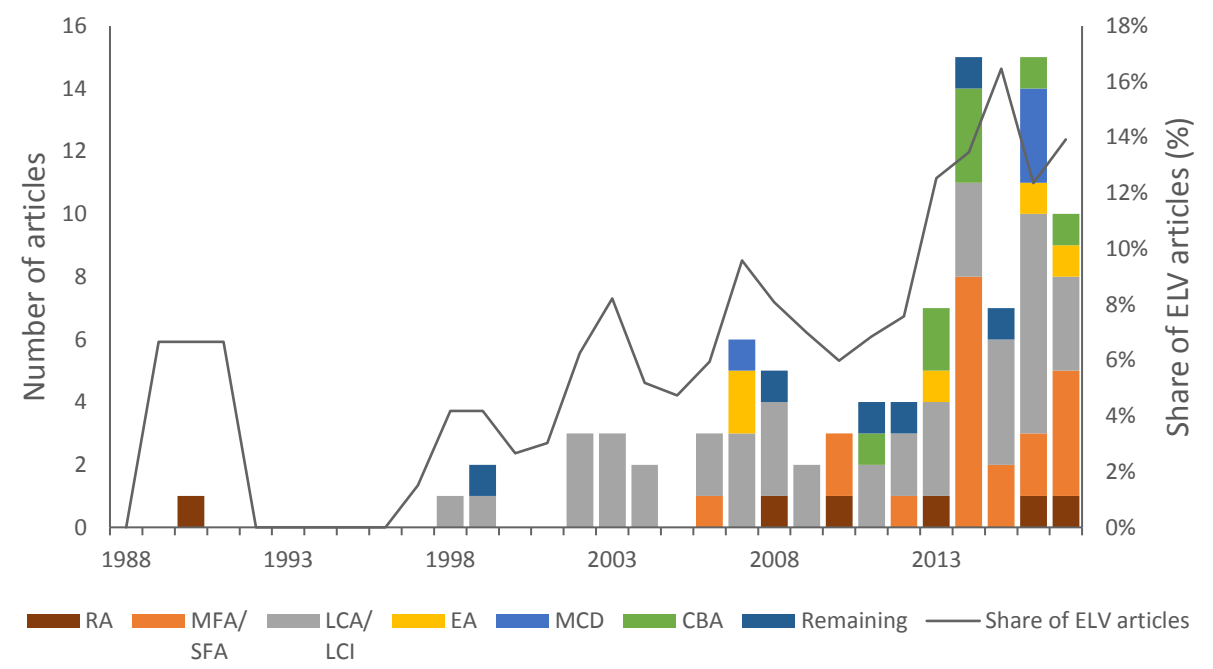

Figure 5. Number of articles per year, and the annual share (displayed as a three-year moving average) of all ELV articles, published in 1988-2017 mentioning an ESA approach. Articles mentioning risk assessment are reported as "RA", material flow accounting/analysis or substance flow analysis as "MFA/SFA", life cycle assessment/inventory as "LCA/LCI", energy, entropy, emergy or exergy analysis as "EA", multi criteria decision making as "MCD", cost-benefit analysis as "CBA", other studied approaches as "Remaining". 


\subsection{Quantification and Characterisation of other WEEE and ELV Articles}

The number of articles that do not use any terms related to the selected research approaches amount to about $90 \%$ of the total sample of WEEE and ELV papers (Tables 4 and 5). To reduce this number, we only examine groups of articles that are linked in citation networks. Figures 6 and 7 show citation networks of articles published in 2008-2017 from the WEEE and ELV fields, respectively, that do not use any terms related to the selected research approaches.

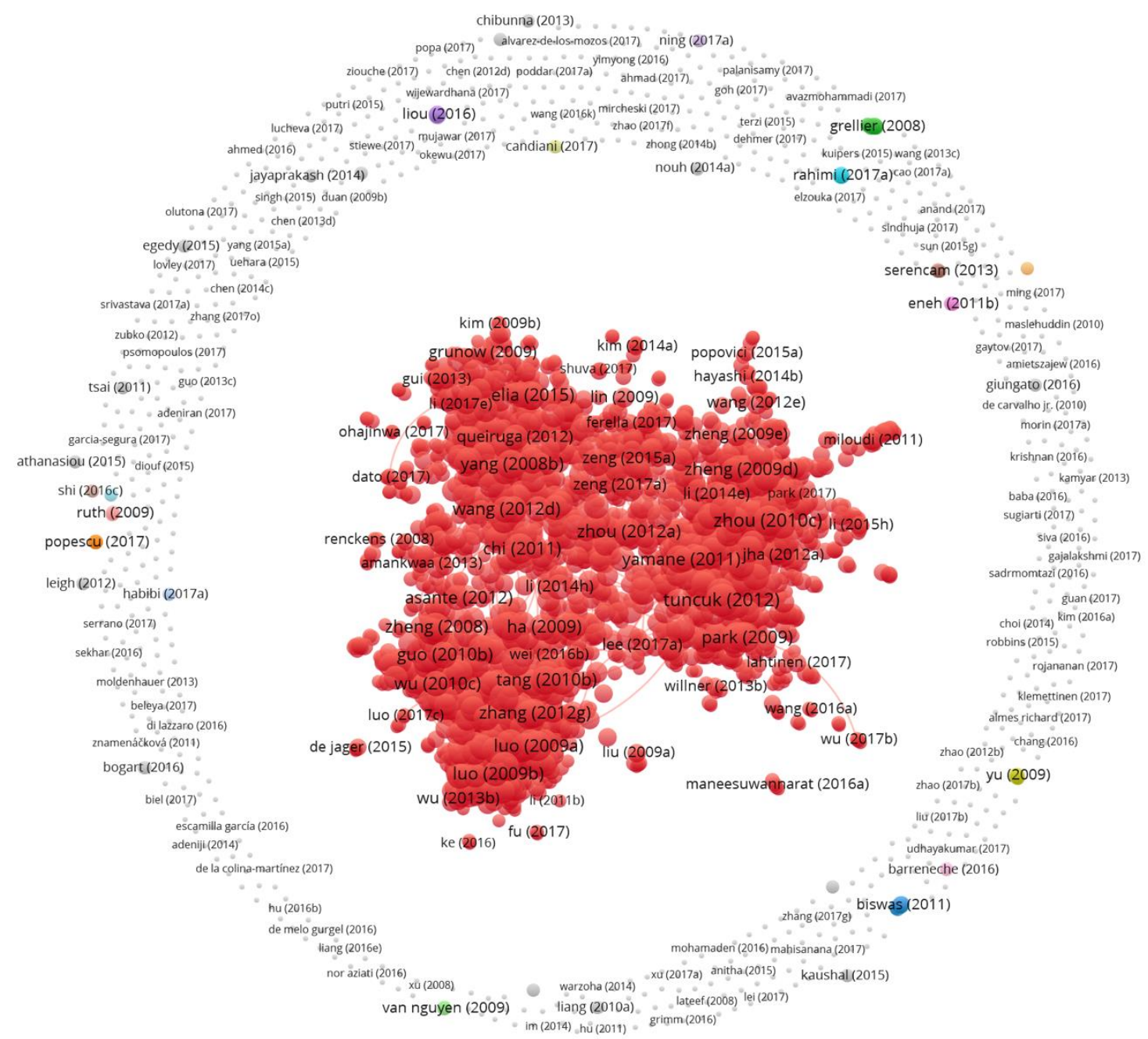

Figure 6. Groups of WEEE articles published in 2008-2017 that cite each other and do not use any terms related to the selected research approaches. Coloured dots represent articles referencing each other. Grey dots are single articles not referencing other articles. The largest group contains 2110 articles, i.e., $70 \%$ of all articles displayed. 


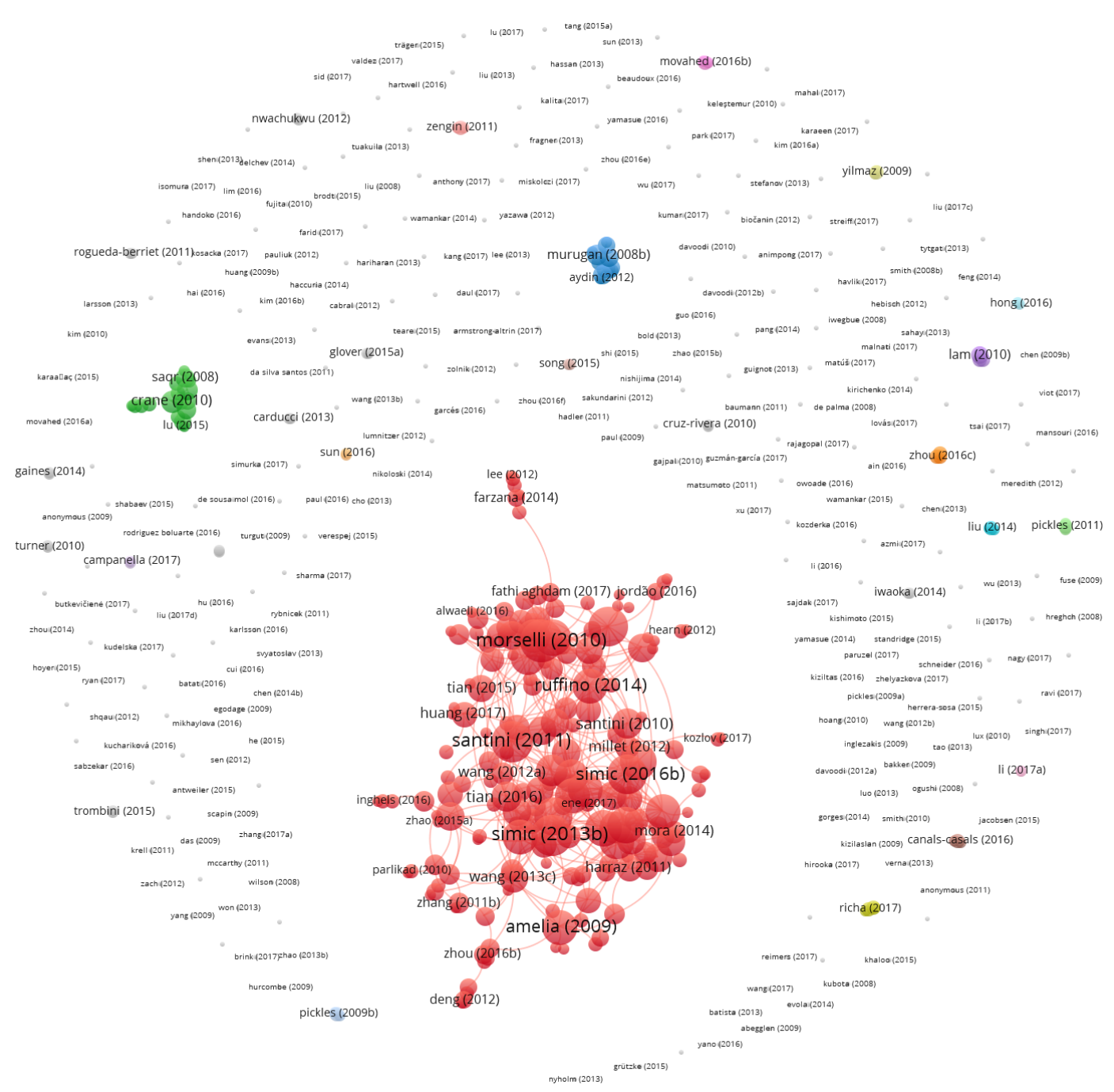

Figure 7. Groups of ELV articles published in 2008-2017 that cite each other and do not use any terms related to the selected research approaches. Coloured dots represent articles referencing each other. Grey dots are single articles not referencing other articles. The largest group contains 174 articles, i.e., $30 \%$ of all articles displayed, and thus constitutes a significant body of literature within the ELV field.

Figure 6 shows that among WEEE articles there is one salient group made up of 2110 articles, i.e., $70 \%$ of the total number of articles in the period. Some smaller groups also exist, but the majority of the remaining articles are unconnected articles dealing with a large variety of topics (corresponding to $28 \%$ of the sample). Although the one salient group of connected articles is too large to study in detail, among the 200 highest cited articles there is a strong emphasis on two approaches (Table 6). The first is the analysis of impacts on local environments or on human health by toxic or in other ways hazardous substances present in WEEE (see e.g., [53-55]). The second is the assessment or experimental evaluation of manual procedures, automated waste treatment or metal recovery processes (see e.g., references [56-58]). Articles dedicated to toxicity/hazard analysis tend to focus on the local environment in a specific region or in smaller areas around WEEE treatment operations, or alternatively on health implications for specific populations that have been exposed to hazardous conditions. Assessments and experimental studies instead focus on the extent to which it is technically possible or manually feasible to perform a certain waste treatment or metal recovery procedure. Additionally, 11 other types of approaches can be identified (Table 6). 
Table 6. Types of approaches used (according to our characterisation) by the 200 highest cited articles, in the largest identifiable group of WEEE articles that cite each other. Period 2008-2017.

\begin{tabular}{lcc}
\hline \multicolumn{1}{c}{ Type of Approach } & Number & Share (\%) \\
\hline Toxicity/Hazard analysis, of impact of various WEEE materials/treatment & 83 & $42 \%$ \\
procedures on local environment/population & 43 & $22 \%$ \\
Technical assessment/experiment, of technical processes or manual procedures & 9 & $5 \%$ \\
Policy analysis & 8 & $4 \%$ \\
Characterisation/Chemical analysis, of various WEEE products/materials & 8 & $4 \%$ \\
Framework development, for technical/economic/environmental assessment of & 8 & $4 \%$ \\
processes or manual procedures & 8 & $4 \%$ \\
General, country specific, overview of WEEE management & 7 & $4 \%$ \\
Modelling and optimisation, of technical processes, manual procedures or logistics & 6 & $3 \%$ \\
Survey, on attitudes/behaviours regarding WEEE collection/treatment & 6 & $3 \%$ \\
Comparison of recycling industries in multiple countries & 5 & $3 \%$ \\
Other & 5 & $3 \%$ \\
Technology review & 4 & $2 \%$ \\
Waste generation estimation & 4 & $100 \%$ \\
Technical assessment/experiment, of processes for generating new composite & 200 & \\
materials from waste & & \\
SUM & & \\
\hline
\end{tabular}

Figure 7 shows that among ELV articles, the largest group is made up of 174 articles, i.e., $30 \%$ of the total number of articles. As in the WEEE field, there are a number of additional smaller groups, but the majority of remaining articles are unconnected (corresponding to $55 \%$ of the sample). Table 7 shows the types of approaches used in the largest group according to our characterisation. There is an emphasis on technically oriented assessments or experiments (see e.g., [59,60]), along with modelling and optimisation of technical processes, manual procedures or waste logistics (see e.g., [61,62]). Similar to articles in the WEEE field, assessment and experimental studies emphasise analysis of technical or manual feasibility to perform waste treatment procedures. Modelling and optimisation studies tend to instead mathematically model and optimise a limited set of technical processes, manual procedures or waste logistics operations. Characterisation or chemical analyses of waste materials also make up a notable share (see e.g., [63,64]), while ten other types of approaches could be identified as well (Table 7).

Table 7. Types of approaches used (according to our characterisation) among the largest identifiable group of ELV articles that cite each other. Period 2008-2017.

\begin{tabular}{lcc}
\hline \multicolumn{1}{c}{ Type of Approach } & Number & Share (\%) \\
\hline Technical assessment/experiment, of technical processes or manual procedures & 53 & $30 \%$ \\
Modelling and optimisation, of technical processes, manual procedures or logistics & 46 & $26 \%$ \\
Characterisation/Chemical analysis, of various materials & 18 & $10 \%$ \\
Policy analysis & 11 & $6 \%$ \\
General, country specific, overview of recycling industries & 8 & $5 \%$ \\
Other & 8 & $5 \%$ \\
Survey, on ELV industry conditions or public perception of ELV management & 6 & $3 \%$ \\
Technology review & 6 & $3 \%$ \\
Economic assessment, of technical processes or manual procedures & 5 & $3 \%$ \\
Toxicity analysis, of various materials & 5 & $3 \%$ \\
Design for recycling & 3 & $2 \%$ \\
Waste generation estimation & 3 & $2 \%$ \\
SWOT analysis & 2 & $1 \%$ \\
SUM & 174 & $100 \%$ \\
\hline
\end{tabular}




\section{Discussion}

Results indicate that only a marginal set of currently conducted research in the WM, WEEE and ELV fields has adopted widely acknowledged ESA and ST approaches. Nevertheless, in the WM field some ESA approaches are fairly well-established. As shown, a significant share of articles containing terms that can be associated with use of life cycle assessment/inventory, material flow accounting/analysis, substance flow analysis and emergy analysis are also WM related.

However, some observable ongoing trends in adoption of approaches may moderate this picture over time. The share of WM and WEEE articles that use ESA terms has been growing moderately over the last 30 years, seemingly largely due to the adoption of life cycle assessment/inventory, material flow accounting/analysis, substance flow analysis and risk assessment methods. Also, the number of ELV articles taking on life cycle assessment/inventory and material flow accounting/analysis or substance flow analysis methods appears to be increasing. In contrast, ST approaches do not show any clear signs of being adopted. Only in the broader WM field are there signs of ST approaches being used to some extent in recent years.

Regarding WEEE and ELV research specifically, significant bodies of articles are using other analytical lenses than ESA or ST approaches. A significant number of WEEE articles analyse the impacts on local environments or human health by toxic or in other ways hazardous WEEE substances. Many WEEE studies also focus on assessing the technical or manual feasibility of certain waste treatment or metal recovery procedures. Such technically oriented assessments are also common in the ELV field. Additionally, many ELV articles aim to model and optimise one or multiple waste treatment procedures or logistic operations, with regard to time, cost or recycling rates. Characterisation, or chemical and toxicity analyses, of ELV waste materials are also frequently made.

The results are partly unsurprising since developing safe, effective and efficient waste management operations are key to all waste management research. However, as indicated by the other characterized WEEE and ELV articles (Tables 6 and 7), complementary perspectives dealing with e.g. policy analysis, country specific industry challenges, theoretical developments, and assessments of softer aspects such attitudes and behaviours towards waste management are also relevant in order to further develop waste management industries. Such aspects have been studied fruitfully in other empirical fields using the ST approaches in Table 1. In these fields, it is emphasized how such aspects may intertwine to create systemic and socio-technical blocking mechanisms preventing desired developments. With that in mind, the overall lack of ST approaches is somewhat surprising. Instead, the characterised articles tend to address one problem at a time, with the risk of foregoing relevant insight into how a wider set of aspects may impact the development of waste management industries.

It should be noted that there is a large number of uncharacterised articles in this study. However, many of them are not referencing the major groups of articles that make up considerable shares of publications in an empirical field and may therefore not drive major knowledge developments. Some are unrelated to waste management, i.e., are undesirable in the sample, while others may treat relevant waste management issues. In the latter case, it means that some relevant waste management research is not well-integrated into main bodies of research, which in itself is problematic. 


\section{Conclusions}

Although systemic and socio-technical research approaches may play important roles in research associated with waste management in general and with WEEE and ELV management, the share of publications mentioning these approaches is low in current research.

Among the 31 environmental system analysis (ESA) and socio-technical (ST) research approaches selected for this paper, ESA approaches are mentioned most frequently in current research. Additionally, there is a trend of increased mentioning of ESA approaches. In contrast, ST approaches are scarcely mentioned, and although there are indications that ST approaches have been mentioned more frequently in waste management research in recent years, there is not yet a clear trend. Moreover, the absolute majority of conducted waste management, WEEE and ELV research uses none of the here identified ESA and ST approaches.

In conclusion, ESA research approaches are mentioned to a minor extent in waste management, WEEE and ELV research fields but are being mentioned at a moderately growing rate in the former two fields. This implies that systemic perspectives are rarely but to some extent increasingly being adopted. However, the lack of explicit referrals to ST approaches implies that current research within the studied empirical fields may forego relevant insight into how socio-technical aspects impact on the development of waste management industries. Thereby, relevant pieces of the puzzle for how to achieve a sustainable supply of a variety of materials may be overlooked.

Author Contributions: Investigation (data collection), M.A.; writing—original draft preparation, M.A.; Other activities shared by all authors.

Funding: This research was funded by the Swedish Foundation for Strategic Environmental Research, Mistra, as part of the project 'Explore-Exploring the opportunities for advancing vehicle recycling industrialization' within the programme 'Closing the Loop' [65], and the programme 'REES-Resource Efficient and Effective Solutions' [66].

Conflicts of Interest: The authors declare no conflict of interest.

\section{Appendix A}

Our conversion of selected research approaches to search strings are displayed in Table A1. Furthermore, details on the execution of initial search queries and our selection of keywords are displayed in Tables A2-A5. The selected keywords were picked from the top 30 most frequently used keywords in the articles making up the results, and included both author and indexed keywords.

We can see from Table A2 that the search term "waste management" is associated with keywords (which we selected) related to recycling, composting, incineration, disposal, landfilling and three types of waste namely solid, industrial and hazardous waste. The search term "circular economy" is connected to keywords related not only to management of waste but of industrial activities (Table A3). We selected the keywords "industrial ecology" and "industrial symbiosis" since these are arguably associated with waste management in an industrial context, yet did not show up when searching for "waste management". Regarding the remaining search queries, we selected some keywords related to "electrical waste", "electronic waste", "end-of-life vehicle(s)" and "end-of-life car(s)" to provide some variety in the final selection of terms (Tables A4 and A5). These latter most selected keywords were also combined with "recycling", "waste", and "scrap", which are words that showed up as keywords (Tables A4 and A5). This was done to reduce the number of highly irrelevant results that would otherwise have been yielded.

Our final selection of search terms and search strings for each empirical field is displayed in Table A6. For each field, search strings separated by "OR" operators were used to form search queries and generate results (Table A6). 
Table A1. Search strings used to represent selected research approaches.

\begin{tabular}{|c|c|}
\hline Research Approach & Search String \\
\hline \multicolumn{2}{|l|}{ ESA approaches } \\
\hline Cost-benefit analysis & $\begin{array}{c}\text { \{cost benefit analysis\} OR \{cost-benefit analysis\} OR } \text { \{cost } \\
\text { benefit analyses\} OR \{cost-benefit analyses\} }\end{array}$ \\
\hline Eco-efficiency analysis & \{eco efficiency\} \\
\hline Ecological footprint & \{ecological footprint $\}$ \\
\hline Emergy analysis & \{emergy analysis\} OR \{emergy analyses\} \\
\hline Energy analysis & \{energy analysis\} OR \{energy analyses\} \\
\hline Entropy analysis & \{entropy analysis\} OR \{entropy analyses\} \\
\hline Environmental impact assessment & $\begin{array}{c}\text { \{environmental impact assessment }\} \text { OR }\{\text { environmental } \\
\text { impact assessments }\}\end{array}$ \\
\hline Exergy analysis & \{exergy analysis\} OR \{exergy analyses\} \\
\hline Input-output analysis & $\begin{array}{c}\text { \{input output analysis\} OR \{input output analyses\} OR } \\
\text { \{input-output analysis\} OR \{input-output analyses\} }\end{array}$ \\
\hline Life cycle assessment & $\begin{array}{c}\text { \{life cycle assessment\} OR \{life-cycle assessment\} OR }\{\text { life } \\
\text { cycle assessments\} OR \{life-cycle assessments\} }\end{array}$ \\
\hline Life cycle costing & \{life cycle inventory\} OR \{life-cycle inventory\} \\
\hline Life cycle inventory & $\{$ life cycle costing $\}$ OR \{life-cycle costing $\}$ \\
\hline Material flow accounting/analysis & $\begin{array}{c}\text { \{material flow accounting\} OR \{material flow analysis\} OR } \\
\text { \{material flow analyses\} }\end{array}$ \\
\hline Multi criteria decision making & $\begin{array}{c}\text { \{multi criteria decision }\} \text { OR }\{\text { multi-criteria decision }\} \text { OR } \\
\text { \{multi-criteria-decision }\} \text { OR }\{\text { multi criteria decision-making }\} \\
\text { OR \{multi-criteria decision-making }\} \text { OR } \\
\text { \{multi-criteria-decision-making }\}\end{array}$ \\
\hline Risk assessment & \{risk assessment\} OR \{risk assessments\} \\
\hline Stakeholder analysis & \{stakeholder analysis\} OR \{stakeholder analyses\} \\
\hline Strategic environmental assessment & $\begin{array}{c}\text { \{strategic environmental assessment\} OR \{strategic } \\
\text { environmental assessments\} }\end{array}$ \\
\hline Substance flow analysis & \{substance flow analysis\} OR \{substance flow analyses\} \\
\hline Systems of environmental and economic accounting & \{systems of environmental and economic accounting\} \\
\hline \multicolumn{2}{|l|}{ ST approaches } \\
\hline Actor-network theory & \{actor network theory\} OR \{actor-network theory\} \\
\hline Discourse theory & $\{$ discourse theory\} \\
\hline Large technical systems & \{large technical system\} OR \{large technical systems\} \\
\hline $\begin{array}{l}\text { The multi-level perspective on socio-technical } \\
\text { transitions }\end{array}$ & $\begin{array}{c}\text { \{multi-level perspective }\} \text { OR \{multi level perspective } \text { OR } \\
\text { \{sociotechnical transition\} OR \{sociotechnical transitions\} OR } \\
\text { \{socio-technical transition\} OR \{socio-technical transitions\} }\end{array}$ \\
\hline National innovation systems & $\begin{array}{c}\text { \{national innovation system }\} \text { OR \{national innovation } \\
\text { systems\} }\end{array}$ \\
\hline Regional innovation systems & $\begin{array}{l}\text { \{regional innovation system }\} \text { OR \{regional innovation } \\
\text { systems\} }\end{array}$ \\
\hline Sectoral systems of innovation and production & $\begin{array}{c}\text { \{sectoral systems of innovation\} OR \{sectoral system of } \\
\text { innovation\} OR \{sectoral innovation system\} OR \{sectoral } \\
\text { innovation systems\} }\end{array}$ \\
\hline Social construction of technology & $\{$ social construction of technology\} \\
\hline Social practice theory & \{practice theory\} \\
\hline Strategic niche management & \{strategic niche management\} \\
\hline Technological innovation systems & $\begin{array}{c}\text { \{technological innovation system\} OR \{technological } \\
\text { innovation systems\} }\end{array}$ \\
\hline Transition management & $\{$ transition management $\}$ \\
\hline
\end{tabular}


Table A2. Details on initial searches used to generate keywords for the empirical field "Waste management". Keywords in bold were selected as complementary search terms to "waste management" for representing the field.

\begin{tabular}{|c|c|c|c|c|}
\hline $\begin{array}{l}\text { Initial Search } \\
\operatorname{Term}(\mathbf{s})\end{array}$ & $\begin{array}{l}\text { No. of } \\
\text { Search } \\
\text { Results }\end{array}$ & $\begin{array}{c}\text { Top } 30 \text { Associated } \\
\text { Keyword(s) } \\
\text { Provided by } \\
\text { Scopus }\end{array}$ & $\begin{array}{l}\text { No. of Articles } \\
\text { among Results } \\
\text { Using keyword(s) }\end{array}$ & $\begin{array}{l}\text { Share of Results } \\
\text { Using keyword(s) }\end{array}$ \\
\hline \multirow[t]{31}{*}{ Waste management ${ }^{1}$} & 22131 & & & \\
\hline & & Article & 6932 & $31 \%$ \\
\hline & & Priority journal & 3889 & $18 \%$ \\
\hline & & Waste disposal & 3763 & $17 \%$ \\
\hline & & Recycling & 2926 & $13 \%$ \\
\hline & & $\begin{array}{l}\text { Municipal solid } \\
\text { waste }\end{array}$ & 1961 & $9 \%$ \\
\hline & & $\begin{array}{l}\text { Solid waste } \\
\text { management }\end{array}$ & 1777 & $8 \%$ \\
\hline & & Air pollution & 1706 & $8 \%$ \\
\hline & & Solid wastes & 1670 & $8 \%$ \\
\hline & & Landfill & 1566 & $7 \%$ \\
\hline & & Solid waste & 1551 & $7 \%$ \\
\hline & & United States & 1538 & $7 \%$ \\
\hline & & Human & 1512 & $7 \%$ \\
\hline & & $\begin{array}{l}\text { Environmental } \\
\text { impact }\end{array}$ & 1426 & $6 \%$ \\
\hline & & Refuse disposal & 1387 & $6 \%$ \\
\hline & & Waste treatment & 1331 & $6 \%$ \\
\hline & & $\begin{array}{l}\text { Environmental } \\
\text { protection }\end{array}$ & 1260 & $6 \%$ \\
\hline & & Incineration & 1153 & $5 \%$ \\
\hline & & Controlled study & 1028 & $5 \%$ \\
\hline & & Methodology & 1009 & $5 \%$ \\
\hline & & Humans & 987 & $4 \%$ \\
\hline & & $\begin{array}{l}\text { Sustainable } \\
\text { development }\end{array}$ & 952 & $4 \%$ \\
\hline & & Nonhuman & 912 & $4 \%$ \\
\hline & & $\begin{array}{l}\text { Environmental } \\
\text { monitoring }\end{array}$ & 892 & $4 \%$ \\
\hline & & Composting & 850 & $4 \%$ \\
\hline & & Land fill & 844 & $4 \%$ \\
\hline & & Hazardous waste & 813 & $4 \%$ \\
\hline & & Particulate matter & 812 & $4 \%$ \\
\hline & & Decision making & 811 & $4 \%$ \\
\hline & & $\begin{array}{c}\text { Environmental } \\
\text { management }\end{array}$ & 792 & $4 \%$ \\
\hline & & Industrial waste & 786 & $4 \%$ \\
\hline
\end{tabular}

1 Search query: TITLE-ABS (waste W/5 management) OR AUTHKEY (waste W/5 management) AND (LIMIT-TO (SRCTYPE, “j”)) AND (LIMIT-TO (DOCTYPE, “ar")) AND (EXCLUDE (PUBYEAR, 2018)). 
Table A3. Details on initial searches used to generate keywords for the empirical field "Waste management". Keywords in bold were selected as complementary search terms to "circular economy" for representing the field.

\begin{tabular}{|c|c|c|c|c|}
\hline $\begin{array}{l}\text { Initial Search } \\
\text { Term(s) }\end{array}$ & $\begin{array}{l}\text { No. of } \\
\text { Search } \\
\text { Results }\end{array}$ & $\begin{array}{l}\text { Top } 30 \text { Associated } \\
\text { Keyword(s) } \\
\text { Provided by Scopus }\end{array}$ & $\begin{array}{l}\text { No. of Articles } \\
\text { among Results } \\
\text { Using Keyword(s) }\end{array}$ & $\begin{array}{l}\text { Share of Results } \\
\text { Using Keyword(s) }\end{array}$ \\
\hline \multirow[t]{31}{*}{ Circular economy ${ }^{1}$} & 980 & & & \\
\hline & & Recycling $^{2}$ & 204 & $21 \%$ \\
\hline & & $\begin{array}{l}\text { Sustainable } \\
\text { development }\end{array}$ & 196 & $20 \%$ \\
\hline & & Economics & 157 & $16 \%$ \\
\hline & & Waste management ${ }^{2}$ & 147 & $15 \%$ \\
\hline & & Article & 134 & $14 \%$ \\
\hline & & Sustainability & 110 & $11 \%$ \\
\hline & & China & 104 & $11 \%$ \\
\hline & & $\begin{array}{l}\text { Environmental } \\
\text { impact }\end{array}$ & 74 & $8 \%$ \\
\hline & & Life cycle & 73 & $7 \%$ \\
\hline & & Industrial economics & 73 & $7 \%$ \\
\hline & & Industrial ecology & 63 & $6 \%$ \\
\hline & & Economic analysis & 56 & $6 \%$ \\
\hline & & $\begin{array}{l}\text { Environmental } \\
\text { protection }\end{array}$ & 55 & $6 \%$ \\
\hline & & Priority journal & 55 & $6 \%$ \\
\hline & & $\begin{array}{l}\text { Environmental } \\
\text { economics }\end{array}$ & 54 & $6 \%$ \\
\hline & & Waste disposal ${ }^{2}$ & 53 & $5 \%$ \\
\hline & & Life cycle analysis & 50 & $5 \%$ \\
\hline & & $\begin{array}{c}\text { Economic } \\
\text { development }\end{array}$ & 49 & $5 \%$ \\
\hline & & Procedures & 49 & $5 \%$ \\
\hline & & Life cycle assessment & 47 & $5 \%$ \\
\hline & & $\begin{array}{c}\text { Economic and social } \\
\text { effects }\end{array}$ & 46 & $5 \%$ \\
\hline & & Efficiency & 46 & $5 \%$ \\
\hline & & Recovery & 44 & $4 \%$ \\
\hline & & $\begin{array}{l}\text { Industrial } \\
\text { symbiosis }\end{array}$ & 44 & $4 \%$ \\
\hline & & Ecology & 43 & $4 \%$ \\
\hline & & Climate change & 40 & $4 \%$ \\
\hline & & $\begin{array}{l}\text { Material flow } \\
\text { analysis }\end{array}$ & 40 & $4 \%$ \\
\hline & & $\begin{array}{l}\text { Environmental } \\
\text { management }\end{array}$ & 40 & $4 \%$ \\
\hline & & Carbon dioxide & 39 & $4 \%$ \\
\hline & & Decision making & 39 & $4 \%$ \\
\hline
\end{tabular}


Table A4. Details on initial searches used to generate keywords for the empirical field "WEEE". Keywords in bold were selected as complementary search terms to "Electrical waste" and "Electronic waste" for representing the field.

\begin{tabular}{|c|c|c|c|c|}
\hline $\begin{array}{l}\text { Initial Search } \\
\text { Term(s) }\end{array}$ & $\begin{array}{l}\text { No. of } \\
\text { Search } \\
\text { Results }\end{array}$ & $\begin{array}{c}\text { Top } 30 \text { Associated } \\
\text { Keyword(s) } \\
\text { Provided by } \\
\text { Scopus }\end{array}$ & $\begin{array}{l}\text { No. of Articles } \\
\text { among Results } \\
\text { Using Keyword(s) }\end{array}$ & $\begin{array}{l}\text { Share of Results } \\
\text { Using Keyword(s) }\end{array}$ \\
\hline \multirow[t]{31}{*}{$\begin{array}{l}\text { Electrical waste or } \\
\text { Electronic waste }\end{array}$} & 2429 & & & \\
\hline & & Recycling & 901 & $37 \%$ \\
\hline & & Article & 788 & $32 \%$ \\
\hline & & $\begin{array}{c}\text { Electronic } \\
\text { equipment }\end{array}$ & 758 & $31 \%$ \\
\hline & & Waste management & 545 & $22 \%$ \\
\hline & & Wastes & 368 & $15 \%$ \\
\hline & & Waste disposal & 362 & $15 \%$ \\
\hline & & $\begin{array}{l}\text { Oscillators } \\
\text { (electronic) }\end{array}$ & 338 & $14 \%$ \\
\hline & & Priority journal & 335 & $14 \%$ \\
\hline & & China & 293 & $12 \%$ \\
\hline & & Controlled study & 260 & $11 \%$ \\
\hline & & E-waste & 260 & $11 \%$ \\
\hline & & $\begin{array}{l}\text { Waste electrical } \\
\text { and electronic } \\
\text { equipment }\end{array}$ & 257 & $11 \%$ \\
\hline & & Electronics & 213 & $9 \%$ \\
\hline & & Lead & 210 & $9 \%$ \\
\hline & & Human & 208 & $9 \%$ \\
\hline & & Copper & 206 & $8 \%$ \\
\hline & & $\begin{array}{l}\text { Environmental } \\
\text { monitoring }\end{array}$ & 190 & $8 \%$ \\
\hline & & WEEE & 190 & $8 \%$ \\
\hline & & Industrial waste & 181 & $7 \%$ \\
\hline & & Waste treatment & 179 & $7 \%$ \\
\hline & & Humans & 178 & $7 \%$ \\
\hline & & Metals & 174 & $7 \%$ \\
\hline & & Analysis & 172 & $7 \%$ \\
\hline & & $\begin{array}{c}\text { Printed circuit } \\
\text { boards }\end{array}$ & 171 & $7 \%$ \\
\hline & & Refuse disposal & 164 & $7 \%$ \\
\hline & & $\begin{array}{l}\text { Environmental } \\
\text { impact }\end{array}$ & 153 & $6 \%$ \\
\hline & & Leaching & 153 & $6 \%$ \\
\hline & & Recovery & 150 & $6 \%$ \\
\hline & & Flame retardants & 149 & $6 \%$ \\
\hline & & Organic pollutants & 139 & $6 \%$ \\
\hline
\end{tabular}

${ }^{1}$ Search query: TITLE-ABS ((electrical W/5 waste) OR (electronic W/5 waste)) OR AUTHKEY ((electrical W/5 waste) OR (electronic W/5 waste)) AND (LIMIT-TO (SRCTYPE, "j")) AND (LIMIT-TO (DOCTYPE, "ar")) AND (EXCLUDE (PUBYEAR, 2018)). 
Table A5. Details on initial searches used to generate keywords for the empirical field "ELVs". Keywords in bold were selected as complementary search terms to "End-of-life vehicle(s)" and "End-of-life car(s)" for representing the field.

\begin{tabular}{|c|c|c|c|c|}
\hline $\begin{array}{l}\text { Initial Search } \\
\text { Term(s) }\end{array}$ & $\begin{array}{l}\text { No. of } \\
\text { Search } \\
\text { Results }\end{array}$ & $\begin{array}{c}\text { Top } 30 \text { Associated } \\
\text { Keyword(s) } \\
\text { Provided by } \\
\text { Scopus }\end{array}$ & $\begin{array}{l}\text { No. of Articles } \\
\text { among Results } \\
\text { Using Keyword(s) }\end{array}$ & $\begin{array}{l}\text { Share of Results } \\
\text { Using Keyword(s) }\end{array}$ \\
\hline \multirow[t]{30}{*}{$\begin{array}{l}\text { End-of-life vehicle(s) } \\
\text { or End-of-life car(s) }^{1}\end{array}$} & 449 & & & \\
\hline & & Recycling & 248 & $55 \%$ \\
\hline & & End-of-life vehicles & 143 & $32 \%$ \\
\hline & & Article & 112 & $25 \%$ \\
\hline & & Waste management & 90 & $20 \%$ \\
\hline & & Automobiles & 82 & $18 \%$ \\
\hline & & Vehicles & 82 & $18 \%$ \\
\hline & & $\begin{array}{l}\text { Scrap metal } \\
\text { reprocessing }\end{array}$ & 61 & $14 \%$ \\
\hline & & Priority Journal & 49 & $11 \%$ \\
\hline & & $\begin{array}{l}\text { Environmental } \\
\text { impact }\end{array}$ & 46 & $10 \%$ \\
\hline & & Waste disposal & 46 & $10 \%$ \\
\hline & & Recovery & 45 & $10 \%$ \\
\hline & & Solid wastes & 45 & $10 \%$ \\
\hline & & $\begin{array}{l}\text { Automotive } \\
\text { industry }\end{array}$ & 43 & $10 \%$ \\
\hline & & Car & 41 & $9 \%$ \\
\hline & & Automobile & 40 & $9 \%$ \\
\hline & & Life cycle & 40 & $9 \%$ \\
\hline & & $\begin{array}{l}\text { Automobile } \\
\text { industry }\end{array}$ & 39 & $9 \%$ \\
\hline & & Motor vehicle & 35 & $8 \%$ \\
\hline & & Landfill & 33 & $7 \%$ \\
\hline & & Aluminum & 32 & $7 \%$ \\
\hline & & $\begin{array}{l}\text { Automobile } \\
\text { manufacture }\end{array}$ & 32 & $7 \%$ \\
\hline & & European union & 31 & $7 \%$ \\
\hline & & Europe & 30 & $7 \%$ \\
\hline & & Metals & 30 & $7 \%$ \\
\hline & & Industrial waste & 29 & $6 \%$ \\
\hline & & Controlled study & 28 & $6 \%$ \\
\hline & & $\begin{array}{c}\text { Automotive } \\
\text { shredder residues }\end{array}$ & 27 & $6 \%$ \\
\hline & & Pyrolysis & 27 & $6 \%$ \\
\hline & & $\begin{array}{l}\text { Sustainable } \\
\text { development }\end{array}$ & 27 & $6 \%$ \\
\hline
\end{tabular}


Table A6. Details on final search terms and search strings used to capture the empirical fields under study. For each field, search strings (column 4) separated by “OR" operators were used to form search queries and generate results.

\begin{tabular}{|c|c|c|c|}
\hline Empirical Field & Initial Search Term(s) & Added Keyword(s) & Final Search String \\
\hline \multicolumn{4}{|c|}{ "Waste management" } \\
\hline & Waste management & $\begin{array}{l}\text { Waste disposal } \\
\text { Recycling }{ }^{1} \\
\text { Municipal solid waste } \\
\text { Solid waste management } \\
\text { Solid waste(s) } \\
\text { Landfill, Land fill } \\
\text { Refuse disposal } \\
\text { Waste treatment } \\
\text { Incineration }{ }^{2} \\
\text { Composting } \\
\text { Hazardous waste } \\
\text { Industrial waste } \\
\text { Industrial ecology } \\
\text { Industrial symbiosis }\end{array}$ & $\begin{array}{l}\text { (waste } W / 5 \text { management) } \\
\text { (waste } W / 5 \text { disposal) } \\
\text { (recycling) } \\
\text { (municipal } W / 5 \text { \{solid waste\}) } \\
\text { (\{solid waste\} } W / 5 \text { management) } \\
\text { (solid } W / 5 \text { waste) } \\
\text { ((landfill) OR \{land fill\} OR \{land fills\}) } \\
\text { (refuse } W / 5 \text { disposal) } \\
\text { (waste } W / 5 \text { treatment) } \\
\text { (waste } W / 5 \text { incineration) } \\
\text { (composting) } \\
\text { (hazardous } W / 5 \text { waste) } \\
\text { (industrial } W / 5 \text { waste) } \\
\text { (circular } W / 5 \text { economy) } \\
\text { (industrial } W / 5 \text { ecology) } \\
\text { (industrial } W / 5 \text { symbiosis) }\end{array}$ \\
\hline \multicolumn{4}{|l|}{ “WEEE" } \\
\hline & $\begin{array}{l}\text { Electrical waste, or } \\
\text { Electronic waste }^{3}\end{array}$ & $\begin{array}{l}\text { E-waste }^{3} \\
\text { WEEE } \\
\text { Printed circuit board(s) }\end{array}$ & 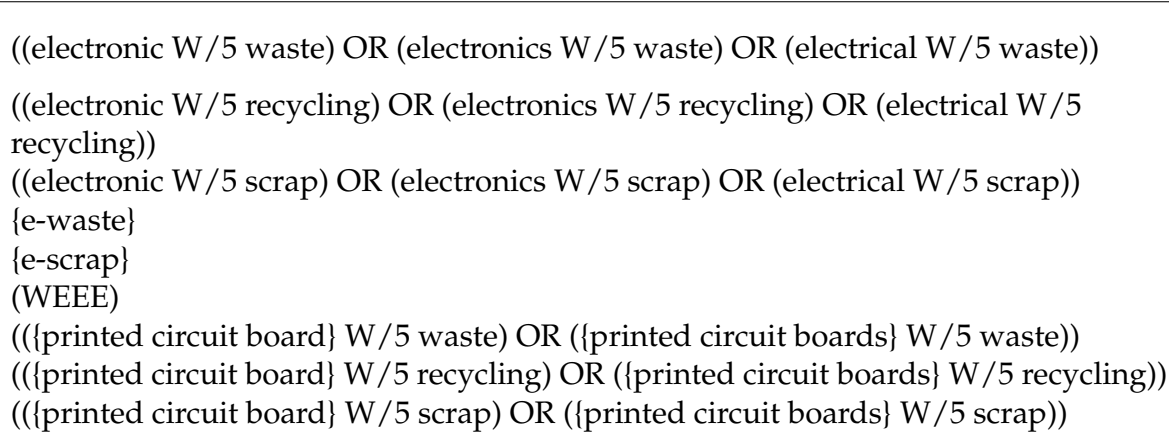 \\
\hline
\end{tabular}


Table A6. Cont.

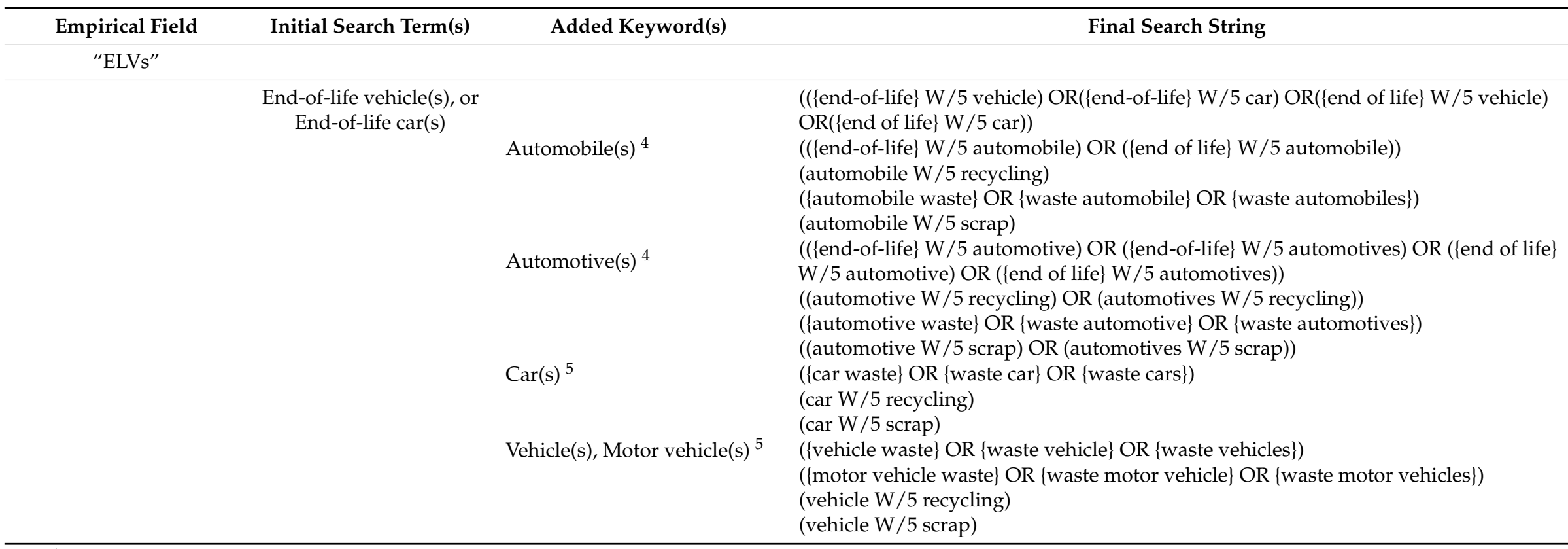

${ }^{1}$ Searches using the string "(recycling)" have been limited to the subject field "Environmental science" in Scopus, since the string otherwise yields too many results not associated with waste management. 2 "waste" has been added to the search string since the string otherwise yields too many results not associated with waste management. 3 "waste", "recycling" or "scrap" have been added to the search string in various ways since the string otherwise yields too many results not associated with waste management. " "end-of-life", "waste", "recycling" or "scrap" have been added to the search string in various ways since the string otherwise yields too many results not associated with waste management. 5 "waste", "recycling" or "scrap" have been added to the search string in various ways since the string otherwise yields too many results not associated with waste management. 


\section{References}

1. Christmann, P. Towards a More Equitable Use of Mineral Resources. Nat. Resour. Res. 2018, $27,159-177$. [CrossRef]

2. UNEP. Metal Recycling: Opportunities, Limits, Infrastructure. 2013. Available online: http:/ /wedocs.unep. org/handle/20.500.11822/8423 (accessed on 20 March 2019).

3. European Commission. Study on the Review of the List of Critical Raw Materials; European Commission: Brussels, Belgium, 2017.

4. U.S. Department of Energy. Critical Materials Strategy. 2011. Available online: https://www.energy.gov/ sites/prod/files/DOE_CMS2011_FINAL_Full.pdf (accessed on 20 March 2019).

5. Skinner, B.J. Earth resources. Proc. Natl. Acad. Sci. USA 1979, 76, 4212-4217. [CrossRef] [PubMed]

6. Andersson, M.; Ljunggren Söderman, M.; Sandén, B.A. Are scarce metals in cars functionally recycled? Waste Manag. 2017, 60, 407-416. [CrossRef] [PubMed]

7. Holgersson, S.; Steenari, B.-M.; Björkman, M.; Cullbrand, K. Analysis of the metal content of small-size Waste Electric and Electronic Equipment (WEEE) printed circuit boards-Part 1: Internet routers, mobile phones and smartphones. Resour. Conserv. Recycl. 2018, 133, 300-308. [CrossRef]

8. Huisman, J.; Leroy, P.; Tertre, F.; Ljunggren Söderman, M.; Chancerel, P.; Cassard, D.; Løvik, A.N.; Wäger, P.; Kushnir, D.; Rotter, V.S.; et al. Prospecting Secondary Raw Materials in the Urban Mine and mining Wastes (ProSUM-Final Report). 2017. Available online: prosumproject.eu/sites/default/files/DIGITAL_Final_Report.pdf (accessed on 20 March 2019).

9. Restrepo, E.; Løvik, A.N.; Wäger, P.; Widmer, R.; Lonka, R.; Müller, D.B. Stocks, Flows, and Distribution of Critical Metals in Embedded Electronics in Passenger Vehicles. Environ. Sci. Technol. 2017, 51, 1129-1139. [CrossRef]

10. Tsydenova, O.; Bengtsson, M. Chemical hazards associated with treatment of waste electrical and electronic equipment. Waste Manag. 2011, 31, 45-48. [CrossRef]

11. Johnson, J.; Harper, E.M.; Lifset, R.; Graedel, T.E. Dining at the Periodic Table: Metals Concentrations as They Relate to Recycling. Environ. Sci. Technol. 2007, 41, 1759-1765. [CrossRef]

12. European Commission. Report on Critical Raw Materials and the Circular Economy; European Commission: Brussels, Belgium, 2018.

13. Graedel, T.E.; Allwood, J.; Birat, J.P.; Buchert, M.; Hagelüken, C.; Reck, B.K.; Sibley, S.F.; Sonnemann, G. What do we know about metal recycling rates? J. Ind. Ecol. 2011, 15, 355-366. [CrossRef]

14. Lehmann, S. Optimizing Urban Material Flows and Waste Streams in Urban Development through Principles of Zero Waste and Sustainable Consumption. Sustainability 2011, 3, 155-183. [CrossRef]

15. UNEP. Recycling Rates of Metals. 2011. Available online: http://www.resourcepanel.org/reports/recyclingrates-metals (accessed on 20 March 2019).

16. Andersson, M.; Ljunggren Söderman, M.; Sandén, B.A. Lessons from a century of innovating car recycling value chains. Environ. Innov. Soc. Transit. 2017, 25, 142-157. [CrossRef]

17. Reuter, M.A.; Van Schaik, A.; Ignatenko, O.; De Haan, G.J. Fundamental limits for the recycling of end-of-life vehicles. Miner. Eng. 2006, 19, 433-449. [CrossRef]

18. Finnveden, G.; Ekvall, T.; Arushanyan, Y.; Bisaillon, M.; Henriksson, G.; Gunnarsson Östling, U.; Söderman, M.L.; Sahlin, J.; Stenmarck, Å.; Sundberg, J.; et al. Policy Instruments towards a Sustainable Waste Management. Sustainability 2013, 5, 841-881. [CrossRef]

19. Reck, B.K.; Graedel, T.E. Challenges in Metal Recycling. Science 2012, 337, 690. [CrossRef]

20. Wilts, H.; Von Gries, N.; Bahn-Walkowiak, B. From Waste Management to Resource Efficiency-The Need for Policy Mixes. Sustainability 2016, 8, 622. [CrossRef]

21. Marshall, R.E.; Farahbakhsh, K. Systems approaches to integrated solid waste management in developing countries. Waste Manag. 2013, 33, 988-1003. [CrossRef]

22. Seadon, J.K. Sustainable waste management systems. J. Clean. Prod. 2010, 18, 1639-1651. [CrossRef]

23. Markard, J.; Raven, R.; Truffer, B. Sustainability transitions: An emerging field of research and its prospects. Res. Policy 2012, 41, 955-967. [CrossRef]

24. Van Den Bergh, J.C.J.M.; Truffer, B.; Kallis, G. Environmental innovation and societal transitions: Introduction and overview. Environ. Innov. Soc. Transit. 2011, 1, 1-23. [CrossRef] 
25. Ekvall, T.; Assefa, G.; Björklund, A.; Eriksson, O.; Finnveden, G. What life-cycle assessment does and does not do in assessments of waste management. Waste Manag. 2007, 27, 989-996. [CrossRef]

26. Finnveden, G. Methodological aspects of life cycle assessment of integrated solid waste management systems. Resour. Conserv. Recycl. 1999, 26, 173-187. [CrossRef]

27. Gentil, E.C.; Damgaard, A.; Hauschild, M.; Finnveden, G.; Eriksson, O.; Thorneloe, S.; Kaplan, P.O.; Barlaz, M.; Muller, O.; Matsui, Y.; et al. Models for waste life cycle assessment: Review of technical assumptions. Waste Manag. 2010, 30, 2636-2648. [CrossRef]

28. Lazarevic, D.; Aoustin, E.; Buclet, N.; Brandt, N. Plastic waste management in the context of a European recycling society: Comparing results and uncertainties in a life cycle perspective. Resour. Conserv. Recycl. 2010, 55, 246-259. [CrossRef]

29. Villanueva, A.; Wenzel, H. Paper waste-Recycling, incineration or landfilling? A review of existing life cycle assessments. Waste Manag. 2007, 27, S29-S46. [CrossRef]

30. Werner, F.; Richter, K. Wooden building products in comparative LCA: A literature review. Int. J. Life Cycle Assess. 2007, 12, 470-479. [CrossRef]

31. Xue, M.; Xu, Z. Application of Life Cycle Assessment on Electronic Waste Management: A Review. Environ. Manag. 2017, 59, 693-707. [CrossRef]

32. Allesch, A.; Brunner, P.H. Material flow analysis as a decision support tool for waste management: A literature review. J. Ind. Ecol. 2015, 19, 753-764. [CrossRef]

33. Lah, T.J. Critical Review of the Cost-Benefit Analysis in the Literature on Municipal Solid Waste Management. Int. Rev. Public Adm. 2002, 7, 137-145. [CrossRef]

34. Daniels, P.L. Approaches for quantifying the metabolism of physical economies: A comparative survey. Part II: Review of individual approaches. J. Ind. Ecol. 2002, 6, 65-88. [CrossRef]

35. Daniels, P.L.; Moore, S. Approaches for quantifying the metabolism of physical economies: Part I: Methodological overview. J. Ind. Ecol. 2001, 5, 69-93. [CrossRef]

36. Finnveden, G.; Björklund, A.; Moberg, Å.; Ekvall, T.; Moberg, Å. Environmental and economic assessment methods for waste management decision-support: Possibilities and limitations. Waste Manag. Res. 2007, 25, 263-269. [CrossRef]

37. Harzing, A.W.; Alakangas, S. Google Scholar, Scopus and the Web of Science: A longitudinal and cross-disciplinary comparison. Scientometrics 2016, 106, 787-804. [CrossRef]

38. Allesch, A.; Brunner, P.H. Assessment methods for solid waste management: A literature review. Waste Manag. Res. 2014, 32, 461-473. [CrossRef]

39. Zurbrügg, C.; Caniato, M.; Vaccari, M. How assessment methods can support solid waste management in developing countries-a critical review. Sustainability 2014, 6, 545-570. [CrossRef]

40. Sovacool, B.K. What are we doing here? Analyzing fifteen years of energy scholarship and proposing a social science research agenda. Energy Res. Soc. Sci. 2014, 1, 1-29. [CrossRef]

41. Sovacool, B.K.; Hess, D.J. Ordering theories: Typologies and conceptual frameworks for sociotechnical change. Soc. Stud. Sci. 2017, 47, 703-750. [CrossRef]

42. Van Eck, N.J.; Waltman, L. Software survey: VOSviewer, a computer program for bibliometric mapping. Scientometrics 2010, 84, 523-538. [CrossRef]

43. Zhang, J.; Di Lucia, L. A transition perspective on alternatives to coal in Chinese district heating. Int. J. Sustain. Energy Plan. Manag. 2015, 6, 49-68. [CrossRef]

44. Elam, M.; Sundqvist, G.R. Meddling in swedish success in nuclear waste management. Environ. Politics 2011, 20, 246-263. [CrossRef]

45. Olsson, L.; Fallde, M. Waste(d) potential: A socio-technical analysis of biogas production and use in Sweden. J. Clean. Prod. 2015, 98, 107-115. [CrossRef]

46. Gee, S.; Uyarra, E. A role for public procurement in system innovation: The transformation of the Greater Manchester (UK) waste system. Technol. Anal. Strateg. Manag. 2013, 25, 1175-1188. [CrossRef]

47. Chan, J.K.Y.; Guan, H.X.; Xu, Y.; Liang, Y.; Ling, X.C.; Sheng, C.W.; Wong, C.K.C.; Leung, C.K.M.; Wong, M.H. Body loadings and health risk assessment of polychlorinated dibenzo-p-dioxins and dibenzofurans at an intensive electronic waste recycling site in China. Environ. Sci. Technol. 2007, 41, 7668-7674. [CrossRef] [PubMed] 
48. Leung, A.O.W.; Duzgoren-Aydin, N.S.; Cheung, K.C.; Wong, M.H. Heavy metals concentrations of surface dust from e-waste recycling and its human health implications in southeast China. Environ. Sci. Technol. 2008, 42, 2674-2680. [CrossRef] [PubMed]

49. Li, H.; Yu, L.; Sheng, G.; Fu, J.; Peng, P. Severe PCDD/F and PBDD/F pollution in air around an electronic waste dismantling area in China. Environ. Sci. Technol. 2007, 41, 5641-5646. [CrossRef] [PubMed]

50. Neyland, D.; Simakova, E. Managing electronic waste: A study of market failure. New Technol. Work Employ. 2012, 27, 36-51. [CrossRef]

51. Lauridsen, E.H.; Jørgensen, U. Sustainable transition of electronic products through waste policy. Res. Policy 2010, 39, 486-494. [CrossRef]

52. Baumann, H.; Tillman, A. The Hitchhiker's Guide to LCA: An Orientation in Life Cycle Assessment Methodology and Application; Studentlitteratur: Lund, Sweden, 2004.

53. Chen, S.-J.; Feng, A.-H.; He, M.-J.; Chen, M.-Y.; Luo, X.-J.; Mai, B.-X. Current levels and composition profiles of PBDEs and alternative flame retardants in surface sediments from the Pearl River Delta, southern China: Comparison with historical data. Sci. Total Environ. 2013, 444, 205-211. [CrossRef]

54. Luo, C.; Liu, C.; Wang, Y.; Liu, X.; Li, F.; Zhang, G.; Li, X. Heavy metal contamination in soils and vegetables near an e-waste processing site, south China. J. Hazard. Mater. 2011, 186, 481-490. [CrossRef] [PubMed]

55. Wu, Q.; Leung, J.Y.S.; Geng, X.; Chen, S.; Huang, X.; Li, H.; Huang, Z.; Zhu, L.; Chen, J.; Lu, Y. Heavy metal contamination of soil and water in the vicinity of an abandoned e-waste recycling site: Implications for dissemination of heavy metals. Sci. Total Environ. 2015, 506-507, 217-225. [CrossRef] [PubMed]

56. Behnamfard, A.; Salarirad, M.M.; Veglio, F. Process development for recovery of copper and precious metals from waste printed circuit boards with emphasize on palladium and gold leaching and precipitation. Waste Manag. 2013, 33, 2354-2363. [CrossRef] [PubMed]

57. Zeng, X.; Song, Q.; Li, J.; Yuan, W.; Duan, H.; Liu, L. Solving e-waste problem using an integrated mobile recycling plant. J. Clean. Prod. 2015, 90, 55-59. [CrossRef]

58. Zhou, Y.; Qiu, K. A new technology for recycling materials from waste printed circuit boards. J. Hazard. Mater. 2010, 175, 823-828. [CrossRef] [PubMed]

59. Santini, A.; Passarini, F.; Vassura, I.; Serrano, D.; Dufour, J.; Morselli, L. Auto shredder residue recycling: Mechanical separation and pyrolysis. Waste Manag. 2012, 32, 852-858. [CrossRef] [PubMed]

60. Taylor, R.; Ray, R.; Chapman, C. Advanced thermal treatment of auto shredder residue and refuse derived fuel. Fuel 2013, 106, 401-409. [CrossRef]

61. Cruz-Rivera, R.; Ertel, J. Reverse logistics network design for the collection of End-of-Life Vehicles in Mexico. Eur. J. Oper. Res. 2009, 196, 930-939. [CrossRef]

62. Simic, V.; Dimitrijevic, B. Production planning for vehicle recycling factories in the EU legislative and global business environments. Resour. Conserv. Recycl. 2012, 60, 78-88. [CrossRef]

63. Mancini, G.; Viotti, P.; Luciano, A.; Fino, D. On the ASR and ASR thermal residues characterization of full scale treatment plant. Waste Manag. 2014, 34, 448-457. [CrossRef]

64. Morselli, L.; Santini, A.; Passarini, F.; Vassura, I. Automotive shredder residue (ASR) characterization for a valuable management. Waste Manag. 2010, 30, 2228-2234. [CrossRef] [PubMed]

65. Swedish Foundation for Strategic Environmental Research Mistra. Explore-Exploring the Opportunities for Advancing Vehicle Recycling Industrialization. Available online: http:/ / closingtheloop.se/aktuella-projekt/ explore/ (accessed on 14 May 2018).

66. Swedish Foundation for Strategic Environmental Research Mistra. REES—Resource Efficient and Effective Solutions. Available online: https:/ / mistrarees.se/ (accessed on 19 February 2019).

(C) 2019 by the authors. Licensee MDPI, Basel, Switzerland. This article is an open access article distributed under the terms and conditions of the Creative Commons Attribution (CC BY) license (http:// creativecommons.org/licenses/by/4.0/). 